\title{
Job Satisfaction in Academia: Why Are Some Faculty Members Happier Than Others?
}

Vicki L. Hesli, University of Iowa

Jae Mook Lee, Yonsei University

ABSTRACT In studying the correlates of job satisfaction among political science faculty we confirm some findings from other disciplines, such as the relationship between institutional type and satisfaction. We demonstrate that those working in top-ranked departments or in private institutions tend to have higher levels of satisfaction with their jobs and with their contributions to the profession. Both job satisfaction and professional satisfaction tend to be highest among full professors; and greater productivity in terms of publishing is independently linked to greater levels of professional satisfaction. In contrast, comparatively higher undergraduate teaching loads undermine professional satisfaction. We also determine that men and women do not differ systematically from one another in their satisfaction levels. We do, however, document significantly lower levels of satisfaction among racial minorities in political science departments. In exploring this finding, we uncover reports of discrimination and dramatic differences in levels of collegiality experienced by different subgroups of faculty members. Experiences with discrimination undermine job satisfaction and are more frequently reported by women than men and are more common among minority faculty than nonminorities.

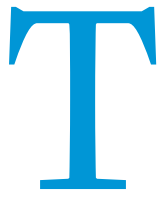

his report analyzes "job satisfaction" among political scientists employed in US institutions of higher education. This study is important because dissatisfaction with any aspect of one's job can lead to depressed productivity and poorer quality of work (Tack and Patitu 1992). The general assumption is that higher satisfaction is associated greater productivity (Bender and Heywood 2006). Given the time that faculty members spend working, poor job satisfaction may result in a lower overall quality of life (Gruneberg 1979). Job satisfaction is also a key predictor of intention to remain in or leave an academic position (Hagedorn 1996; Rosser 2004; Smart 1990). Thus, understanding the factors that

Vicki L. Hesli is a professor in the department of political science at the University of Iowa. She can be reached at vicki-hesli@uiowa.edu.

Jae Mook Lee is a National Research Foundation of South Korea fellow at Yonsei University in Seoul. He can be reached at jaemook@gmail.com contribute to job satisfaction could improve retention among all faculty and among women and minorities who remain underrepresented in political science departments (Hesli, Lee, and Mitchell 2012; US Department of Education [a]).

The evidence that we present is based on a sample of all faculty members in departments of political science (and departments of government, public affairs, and international relations) in the United States (see appendix A for a description of the survey methodology). We find significantly different levels of job satisfaction depending on demographic characteristics as well as the characteristics of the institution within which the faculty member works. We do not find differences in levels of satisfaction between men and women, but we do find lower levels of satisfaction among minority faculty. We also find that levels of professional satisfaction are lower when teaching loads are higher, while satisfaction is greater among those who publish and attend conferences more frequently. Job satisfaction tends to be higher among 
those employed in more highly ranked departments and in private institutions. Satisfaction improves with symbolic recognition such as award nominations.

\section{LITERATURE REVIEW}

Job satisfaction refers "to an overall affective orientation on the part of individuals toward work roles which they are presently occupying" (Kalleberg 1977, 126). Previous studies have identified numerous factors that correlate with variations in levels of job satisfaction. One factor is gender: several studies, some of which are dated, report that male faculty members have higher levels of job satisfaction than female faculty (Bender and Heywood 2009; 2006; Bilimoria et al. 2006; Callister 2006; Hult, Callister, and Sullivan 2005; Olsen, Maple, and Stage 1995; Settles et al. 2006; Tack and Patitu 1992). Other researchers report equal levels of satisfaction for men and women, and in one report, higher satisfaction is found among female faculty (Okpara, Squillace, and Erondu 2005; Oshagbemi 1997; Sabharwal and Corley 2009, 549; Ward and Sloane 200o). In a cross-national study, Sousa-Poza and SousaPoza (2000) report that in eight of 21 countries women report higher job-satisfaction levels than men; in most countries, however, men have higher job-satisfaction levels than women, although the difference is marginal. Thus, although gender is one of the most frequently researched demographics, the evidence remains
Maple, and Stage 1995). Sabharwal and Corley (2009, 551), however, report that African American faculty members are equally, or more, satisfied than their Caucasian counterparts. Ponjuan (2005) found Latino faculty were less satisfied than Caucasian faculty with their overall job duties, but that African American faculty did not statistically differ in their job satisfaction from their Caucasian colleagues (quoted from Seifert and Umbach 2008, 360). Also contrary to most of the literature, Ethington, Smart, and Zeltman (1989) find that minority status is positively related to satisfaction with teaching and institutional recognition and support.

In addition to demographic characteristics, several characteristics of the job affect satisfaction. For example, faculty who work at Carnegie Research I or II universities have higher levels of satisfaction than those who work at other types of universities (Sabharwal and Corley 2009, 551; see also Ethington, Smart, and Zeltman 1989). Faculty members who spend a greater percentage of their time teaching in comparison to research are more likely to express greater dissatisfaction with their work (Bender and Heywood 2009; Liu 2001; Olsen, Maple, and Stage 1995; Sabharwal and Corley 2009, 551). Tenure is usually found to be a powerful predictor of faculty satisfaction (Bender and Heywood 2006; Tack and Patitu 1992). Full professors are reportedly more satisfied than associate or assistant professors (Ethington, Smart, and Zeltman 1989; Oshagbemi 1997; Sabharwal and Corley 2009, 552).

\section{Now, a decade and a halflater, we return to the question of a chilly climate in political science departments, but we embed the question into a broader discussion of the concept of job satisfac- tion. Given the previous findings, we created a survey instrument that allows us to evaluate both job satisfaction and the chilly climate in academia using a comprehensive set of measures.}

mixed with regard to the effects of gender on job satisfaction (Hagedorn 2000). No study has yet focused specifically on job satisfaction among academic political scientists, so this study fills that void and answers the question of whether female faculty have different levels of satisfaction than their male colleagues.

With regard to other demographic characteristics, marriage generally improves job satisfaction (Bender and Heywood 2009, 2006; Cetin 2006; Hagedorn 2000; Leung, Siu, and Spector 2000; Sabharwal and Corley 2009, 552). This finding could work against female faculty as they are less likely to be married than male faculty. (US Department of Education [b]). Exceptions to the finding that marriage improves job satisfaction include Aisenberg and Harrington (1988) and Bryson, Bryson, and Johnson (1978). Although Carr and Ash $(1998,536)$ report that women with children are less satisfied with their careers than men with children, more children is correlated with higher satisfaction (Sabharwal and Corley 2009, 552).

Minority faculty members are typically less satisfied than nonminority faculty (Antonio, Cress, and Astin 1997; Bender and Heywood 2009; Peterson et al. 2004; Rosser 2005). The effect of minority status on job satisfaction depends to some degree on academic rank and on "solo" status within a department (Niemann and Dovidio 1998). In general, the literature suggests that minority workers are likely to experience race-related stressors (Holder and Vaux 1998) and, thus, are more likely to report lower levels of career satisfaction (August and Waltman 2004; Olsen,
Productivity, in terms of research and publication, is regularly found to be a predictor of faculty job satisfaction (August and Waltman 2004; Blackburn and Lawrence 1995; Hagedorn 2000; Lahey and Vihtelic 2000; Olsen, Maple, and Stage 1995; Sabharwal and Corley 2009, 551).

Unsurprisingly, positive social and working relationships are conducive to job satisfaction (Carnevale and Rios 1995). Relationships with colleagues, administrators, and students plus perceptions of culture and climate significantly affect job satisfaction (Austin and Davis 1985; Ethington, Smart, and Zeltman 1989; Hagedorn 1996, 2000). Looking only at female faculty, August and Waltman $(2004,186-7)$ found that among the best predictors of overall satisfaction were measures of the departmental climate and the quality of relations with students. Job satisfaction tends to be higher among those who feel valued and have received rewards and recognition from their peers and institutions. Receiving an adequate and equitable allocation of resources, such as research support and graduate student assistance, is also important to satisfaction levels (Johnsrud and Des Jarlais 1994).

One study, which focused specifically on political scientists, reported that gender and the year of doctoral degree were significant predictors of reports of a chilly climate (Hesli and Burrell 1995). ${ }^{1}$ Women reported inequality in the workplace significantly more frequently than did men. Faculty members who obtained their degrees recently (younger faculty) were significantly more 
likely to perceive a chilly climate than (older) faculty members who obtained their degree earlier. Now, a decade and a half later, we return to the question of a chilly climate in political science departments, but we embed the question into a broader discussion of the concept of job satisfaction. Given the previous findings, we created a survey instrument that allows us to evaluate both job satisfaction and the chilly climate in academia using a comprehensive set of measures.

\section{THEORETICAL FRAMEWORK AND HYPOTHESES}

In setting up the analyses, we needed a theoretical framework to guide our selection of independent variables. Several frameworks are available in the literature for identifying the factors that are expected to influence variations in job-satisfaction levels (Bilimoria et al. 2006; Ethington, Smart, and Zeltman 1989; Kalleberg 1977; Sabharwal and Corley 2009). We employ the rich conceptual framework offered by Hagedorn (2000, 6-7), who identifies three types of mediators that provide the context in which job satisfaction can be considered. These are demographics, motivators and hygienes, and environmental conditions. First, demographics include standard items like gender, family factors, and minority status, but the category also includes institutional characteristics (such as private or public institution, or PhD-granting or fouryear college). The argument is that institutional type creates in-groups of workers who share certain similar characteristics just as do gender and ethnicity (Hagedorn 2000, 9). Second, motivators increase satisfaction, while hygienes decrease satisfaction (according to Herzberg, Mausner, and Snyderman 1959). For academics, motivators include achievement (number of publications), recognition (awards), the nature of the work itself (teaching and research), responsibility (committee service), and advancement (academic rank) (Hagedorn 20oo, table 1.1, 13). Hygienes may include heavy teaching or advising responsibilities. The third category, environmental conditions, encompasses working conditions, including social and working relationships.

We structure our presentation and analyses using the categories of mediators defined by Hagedorn (2000). Her categories applied to our indicators yield three groups of independent variables-to be used to predict variation in levels of job satisfaction (each variable is described in appendix B):

\section{Demographic and Institutional Variables}

1. Gender

2. Married

3. Number of children

4. Minority

5. Year of degree

6. Joint appointment

7. Current department ranking (based on Schmidt and Chingos 2007)

8. Employed in a private (rather than a public) institution

9. Employed in PhD program or an MA program (excluded category is four-year or two-year college)

10. Geographic location-the Northeast, Midwest, or South (excluded category is the West)
Motivators and Hygienes ${ }^{2}$
11. Tenured
12. Resources available (research assistant, travel funds, etc.)
13. Award nominations

14. Professional recognition (editorial board member or professional association committee service)

15. Total of articles and books published

16. Frequency of attending political science conferences

17. Number of undergraduate courses taught

18. New course preparation

19. Release from teaching

20. Mentoring activity

21. Undergraduate advising activity

22. Number of committees

\section{Environmental Conditions}

23. Collegial climate 3

24. Tolerance 4

25. Discrimination experience 5

The two dependent variable measures that provide the foundation for our analyses are job satisfaction and professional satisfaction (the components of these scales are listed in appendix B):

26. Job satisfaction: A three-item scale anchored with the query of "How satisfied are you with your current position?" 6 and also includes questions about being valued by other members of the department and being satisfied with day-to-day contacts with faculty colleagues.

27. Professional satisfaction: A three-item scale based on satisfaction with collaborative opportunities in academia, funding for research, and opportunities to make contributions to theory.

Note that we have two measures of satisfaction. We started with the assumption that we only needed one multiple-item measure, but our testing of the measure revealed that responses to survey questions grouped into two different dimensions; thus we created two distinct scales as indicators of the two different dimensions. Our initial focus will be on explaining job satisfaction and professional satisfaction (as our two primary dependent variables). Later in the text we explore why some faculty members rate their departments as more collegial than others and why some have experienced more discrimination than others.

Based on the literature review and the theoretical framework, our guiding hypotheses are as follows:

H1: After controlling for demographic, institutional, and careerrelated variables, female faculty members experience lower levels of satisfaction than male faculty members.

$\mathrm{H} 2$ : Also with controls, minority faculty members experience lower levels of satisfaction than nonminority faculty members.

$\mathrm{H}_{3}$ : Those who are employed in more highly ranked departments are more satisfied than those who are employed in less highly ranked departments.

$\mathrm{H}_{4}$ : Those who teach less are more satisfied than those who teach more.

$\mathrm{H}_{5}$ : Faculty members in higher academic ranks are more satisfied than those in lower ranks.

H6: Faculty members who publish more are more satisfied than those who publish less.

$\mathrm{H}_{7}$ : Those who rate their departments as collegial and tolerant, and who have not experienced discrimination, are more satisfied than their respective counterparts. 
Table 1

\section{Difference of Means Tests-Men and Women Compared}

\begin{tabular}{l|ccc|ccc|ccc} 
& \multicolumn{3}{|c|}{ ASSISTANT PROFESSORS } & \multicolumn{3}{c|}{ ASSOCIATE PROFESSORS } & \multicolumn{2}{c}{ FULL PROFESSORS } \\
\cline { 2 - 12 } & Men & Women & Significance & Men & Women & Significance & Men & Women & Significance \\
\hline Job Satisfaction & 3.88 & 3.80 & .461 & 3.82 & 3.60 & .110 & 4.01 & 3.85 & .232 \\
\hline Professional Satisfaction & 3.39 & 3.38 & .944 & 3.45 & 3.30 & .241 & 3.76 & 3.72 & .731 \\
\hline Collegial Climate & 3.89 & 3.85 & .687 & 3.77 & 3.54 & .074 & 3.83 & 3.62 & .100 \\
\hline Tolerance & 4.41 & 4.08 & .001 & 4.49 & 3.85 & .001 & 4.46 & 3.98 & .000 \\
\hline Discrimination Experience & .356 & .719 & .031 & .387 & 1.26 & .001 & .302 & .936 & .001 \\
\hline
\end{tabular}

*This table and the following tables are based on tenure-track respondents only. Cell entries are mean scores for men and women at different ranks and $p$ values (significance levels) of t-tests.

Table 2

\section{Difference of Means Tests-Academic Ranks Compared}

\begin{tabular}{l|cccc|cccc} 
& \multicolumn{5}{|c|}{ WOMEN } & \multicolumn{4}{c}{ MEN } \\
\cline { 2 - 9 } & Assistant & Associate & Full & Sig. & Assistant & Associate & Full & Sig. \\
\hline Job Satisfaction & 3.80 & 3.60 & 3.85 & .179 & 3.88 & 3.82 & 4.01 & .154 \\
& & & & .729 & & & .036 \\
\hline Professional Satisfaction & 3.38 & 3.31 & 3.72 & .596 & 3.39 & 3.45 & 3.76 & .734 \\
& & & & .482 & & & .000 \\
\hline Collegial Climate & 3.85 & 3.54 & 3.62 & .021 & 3.89 & 3.77 & 3.83 & .185 \\
& & & & .613 & & & .416 \\
\hline Tolerance & 4.08 & 3.85 & 3.98 & .089 & 4.41 & 4.49 & 4.46 & .285 \\
& & & & .427 & & & .686 \\
\hline Discrimination Experience & .719 & 1.26 & .936 & .050 & .355 & .387 & .302 & .748 \\
& & & & .407 & & & .390 \\
\hline
\end{tabular}

Cell entries are mean scores for different ranks among women and among men. In the columns for "Sig.," the top value represents the $p$ value of the comparison of the means of assistant and associate professors, and the bottom $p$ value is for the comparison of the means of the associate and full professors.

\section{DATA AND FINDINGS}

Table 1 shows difference in means tests for our two satisfaction measures, plus the measures of the environmental conditions. ${ }^{7}$ We see no significant differences between men and women in their levels of satisfaction at any rank. (Our expectation associated with Hypothesis 1 is not confirmed.) We do, however, see significant differences between men and women at each rank in ratings of tolerance within the department and in reports of individual experiences with discrimination. At each rank (assistant, associate, and full professor), women rate their departments as less tolerant (more racist, sexist, and homophobic) than do men; and, at each of the different academic ranks, women report more personal experiences with discrimination than do men.

In table 2, we see that among women only, no differences in satisfaction exist when the average satisfaction score within one academic rank is compared with the average satisfaction score for a different academic rank. However, among men, full professors are on average significantly more satisfied than associate professors. Among women, we see only one difference across the ranks on our measures of the academic environment. An interesting difference is seen on the collegial climate scale between female assistant professors and female associate professors. The female assistant professors on average rate their department as being significantly more collegial than do female associate professors.

We do not discuss the contrasts in tables 1 and 2, because none of these comparisons includes controls for other relevant factors. Thus, we turn to the multivariate analyses based on OLS regression. We run two different sets of regressions, a set for each dependent variable: job satisfaction and professional satisfaction.

Table 3 provides estimated OLS coefficients, standard errors, and indicators of significance for each demographic and institutional predictor of satisfaction. We test these models separately for men and women as we expected that the causes of satisfaction would differ for the two demographic groups. We find that not only are predictors of satisfaction different for men as compared with women, but that predictors of job satisfaction are different from predictors of professional satisfaction. This difference makes our overview more cumbersome. Therefore, we organize our discussion around the independent variables rather than the dependent variables. We first note that given the other controls in the model, married or partnered faculty are no different from their comparative counterparts on either measure of satisfaction, nor are those with joint appointments any different from those who do not have joint appointments. We do find that men with children have greater job satisfaction than men without children; ${ }^{8}$ and that minority female faculty members are less satisfied with their job than are nonminority female faculty. When a woman received her $\mathrm{PhD}$ affects her level of professional satisfaction, as does region of residence, with female academics living in the Northeast and the South having less professional satisfaction than those living in the West (the excluded category). Working in a highly ranked department is associated with higher levels of professional satisfaction for both men and women. Job satisfaction is also higher among women working in the more highly ranked 
Table 3

Demographic and Institutional Predictors of Satisfaction (OLS Regression)

\begin{tabular}{|c|c|c|c|c|}
\hline \multirow[b]{2}{*}{ PREDICTORS } & \multicolumn{2}{|c|}{ JOB SATISFACTION } & \multicolumn{2}{|c|}{ PROFESSIONAL SATISFACTION } \\
\hline & $\begin{array}{c}\text { Women } \\
\text { Coef. (Std. Err.) }\end{array}$ & $\begin{array}{c}\text { Men } \\
\text { Coef. (Std. Err.) }\end{array}$ & $\begin{array}{c}\text { Women } \\
\text { Coef. (Std. Err.) }\end{array}$ & $\begin{array}{c}\text { Men } \\
\text { Coef. (Std. Err.) }\end{array}$ \\
\hline (Constant) & 12.445 (14.694) & 7.783 (7.392) & $27.537(11.866)^{*}$ & $11.725(6.201)$ \\
\hline Married or Partnered & $.134(.174)$ & $.210(.130)$ & $.076(.142)$ & $.113(.109)$ \\
\hline Number of Children & $.053(.063)$ & $.091(.033)^{* *}$ & $.027(.052)$ & $.050(.028)$ \\
\hline Minority & $-.526(.193)^{* *}$ & $-.200(.124)$ & $-.245(.155)$ & $-.178(.104)$ \\
\hline Year of Degree & $-.005(.007)$ & $-.002(.004)$ & $-.012(.006)^{*}$ & $-.004(.003)$ \\
\hline Joint Appointment & $.287(.195)$ & $-.061(.136)$ & $.244(.157)$ & $.087(.115)$ \\
\hline Current Department Rank & $.144(.069)^{*}$ & $.036(.042)$ & $.152(.055)^{* *}$ & $.117(.036)^{* *}$ \\
\hline Private Institution & $.253(.165)$ & $.263(.095)^{* *}$ & .055 (.132) & $.204(.081)^{*}$ \\
\hline PhD Program & $-.277(.241)$ & $.031(.127)$ & $.232(.193)$ & $.469(.107)^{* *}$ \\
\hline MA Program & $.143(.202)$ & $.043(.117)$ & $.170(.162)$ & $.174(.099)$ \\
\hline Northeast Regional Dummy & $-.171(.205)$ & $.070(.127)$ & $-.343(.165)^{*}$ & $-.016(.107)$ \\
\hline Midwest Regional Dummy & $-.229(.213)$ & $.088(.124)$ & $-.263(.170)$ & $-.140(.105)$ \\
\hline South Regional Dummy & $-.157(.216)$ & .109 (.123) & $-.561(.173)^{* *}$ & $-.091(.103)$ \\
\hline R-Squared & .097 & .057 & .205 & .175 \\
\hline No. of Cases & 232 & 550 & 229 & 546 \\
\hline
\end{tabular}

Sig: ** $p<0.01,{ }^{*} p<0.05$

Table 4 A

Motivators and Hygienes as Predictors of Job Satisfaction

\begin{tabular}{|c|c|c|c|c|}
\hline \multirow[b]{2}{*}{ PREDICTORS } & \multicolumn{2}{|c|}{ TENURED ONLY } & \multicolumn{2}{|c|}{ NONTENURED ONLY } \\
\hline & $\begin{array}{l}\text { Women } \\
\text { Coef. (Std. Err.) }\end{array}$ & $\begin{array}{c}\text { Men } \\
\text { Coef. (Std. Err.) }\end{array}$ & $\begin{array}{l}\text { Women } \\
\text { Coef. (Std. Err.) }\end{array}$ & $\begin{array}{c}\text { Men } \\
\text { Coef. (Std. Err.) }\end{array}$ \\
\hline (Constant) & $3.866(.569)^{* * *}$ & $4.193(.242)^{* * *}$ & $4.680(.441)^{* * *}$ & $3.663(.333)^{* * *}$ \\
\hline Overall Resource & $.045(.043)$ & $.046(.018)^{* *}$ & $.062(.046)$ & $.011(.036)$ \\
\hline Award Nominations & $.202(.097)^{* *}$ & $.171(.055)^{* * *}$ & $.118(.173)$ & $.103(.130)$ \\
\hline Professional Recognition & $-.095(.139)$ & $-.121(.074)$ & $-.067(.172)$ & $-.079(.120)$ \\
\hline Total Productivity & $-.108(.150)$ & $-.097(.065)$ & $-.190(.143)$ & $.075(.101)$ \\
\hline Frequency of Attending Conferences & $.031(.036)$ & $-.021(.016)$ & $-.066(.036)^{*}$ & $.010(.014)$ \\
\hline No. of Undergraduate Courses & $.021(.052)$ & $-.011(.023)$ & $-.055(.047)$ & $.030(.035)$ \\
\hline Prepared New Courses & $-.037(.045)$ & $-.033(.023)$ & $.020(.040)$ & $.004(.026)$ \\
\hline Release from Teaching & $.004(.025)$ & $.014(.010)$ & $-.011(.036)$ & $-.061(.037)$ \\
\hline $\begin{array}{l}\text { Time Spent on Informal Mentoring } \\
\text { Activities }\end{array}$ & $-.043(.016)^{* * *}$ & $-.018(.012)$ & $-.028(.027)$ & $.048(.018)^{* * *}$ \\
\hline No. of Undergraduate Advisees & $.002(.002)$ & $-.001(.001)$ & $.005(.006)$ & $-.011(.005)^{* *}$ \\
\hline No. of Committees Served & $-.036(.042)$ & $.011(.020)$ & $-.074(.050)$ & $-.046(.034)$ \\
\hline Full Professor Dummy & $.154(.215)$ & .009 (.109) & & \\
\hline R-Squared & .129 & .102 & .122 & .098 \\
\hline No. of Cases & 129 & 369 & 104 & 149 \\
\hline
\end{tabular}

Sig: ${ }^{* *} p<.01,{ }^{* *} p<0.05,{ }^{*} p<0.10$ departments. Higher levels of both job satisfaction and professional satisfaction are reported by male faculty members working in private institutions. Men working in $\mathrm{PhD}$ granting departments also report higher levels of professional satisfaction than men working in bachelor degreegranting departments (the excluded category).

To examine the effects of motivators and hygienes on satisfaction, as identified in Hagedorn's (2000) conceptual framework, we split the sample not only between men and women but also between those who are tenured and nontenured, and, among the tenured group, we include a dummy variable for whether the respondent is an associate or a full professor. We conduct separate regressions for tenured and nontenured men and tenured and nontenured women as the likelihood of gaining tenure is different for men and women (Hesli, Lee, and Mitchell 2012), and several satisfaction-related issues affect tenured and nontenured faculty differently (Sorcinelli and Austin 1992).

Table 4A is concerned solely with job satisfaction. Recall that our job-satisfaction scale taps into questions about dayto-day interactions with departmental colleagues. The predictor variables from this set that are unrelated to job satisfaction are professional recognition, publication productivity, undergraduate teaching load, new course preparation, teaching release, and committee service. In terms of significant relationships, more resources are associated with more job satisfaction among tenured men. More award nominations are related to greater job satisfaction among both male and female tenured faculty. More frequent conference attendance is related to depressed levels of job satisfaction among 
Table $4 B$

\section{Motivators and Hygienes as Predictors of Professional Satisfaction}

\begin{tabular}{|c|c|c|c|c|}
\hline \multirow[b]{2}{*}{ PREDICTORS } & \multicolumn{2}{|c|}{ TENURED ONLY } & \multicolumn{2}{|c|}{ NONTENURED ONLY } \\
\hline & $\begin{array}{c}\text { Women } \\
\text { Coef. (Std. Err.) }\end{array}$ & $\begin{array}{c}\text { Men } \\
\text { Coef. (Std. Err.) }\end{array}$ & $\begin{array}{c}\text { Women } \\
\text { Coef. (Std. Err.) }\end{array}$ & $\begin{array}{c}\text { Men } \\
\text { Coef. (Std. Err.) }\end{array}$ \\
\hline (Constant) & $2.369(.444)^{* * *}$ & $2.920(.200)^{* * *}$ & $3.679(.423)^{* * *}$ & $3.045(.315)^{* * *}$ \\
\hline Overall Resource & $.039(.032)$ & $.027(.015)^{*}$ & $.088(.044)^{* *}$ & $.003(.034)$ \\
\hline Award Nominations & $-.032(.073)$ & $.101(.045)^{* *}$ & $.188(.166)$ & $.028(.122)$ \\
\hline Professional Recognition & $.165(.104)$ & $.008(.060)$ & $.154(.165)$ & $-.141(.113)$ \\
\hline Total Productivity & $.234(.125)^{*}$ & $.201(.053)^{* * *}$ & $.008(.137)$ & $.298(.097)^{* * *}$ \\
\hline Frequency of Attending Conferences & $.061(.027)^{* *}$ & $.030(.013)^{* *}$ & $.033(.034)$ & $.027(.013)^{* *}$ \\
\hline No. of Undergraduate Courses & $-.020(.039)$ & $-.054(.019)^{* * *}$ & $-.069(.045)$ & $-.054(.032)$ \\
\hline Prepared New Courses & $-.060(.034)^{*}$ & $.006(.019)$ & $-.037(.038)$ & $.002(.024)$ \\
\hline Release From Teaching & $.026(.019)$ & $.013(.008)$ & $.003(.035)$ & $-.019(.035)$ \\
\hline $\begin{array}{l}\text { Time Spent on Informal Mentoring } \\
\text { Activities }\end{array}$ & $-.018(.012)$ & $-.004(.010)$ & $-.048(.026)^{*}$ & $.044(.017)^{* *}$ \\
\hline No. of Undergraduate Advisees & $.001(.002)$ & $-.002(.001)^{* *}$ & $.002(.006)$ & $-.008(.004)^{*}$ \\
\hline No. of Committees Served & $.018(.031)$ & $-.005(.016)$ & $-.088(.048)^{*}$ & $-.034(.032)$ \\
\hline Full Professor Dummy & $.020(.167)$ & $.076(.089)$ & & \\
\hline R-Squared & .326 & .246 & .240 & .242 \\
\hline No. of Cases & 127 & 367 & 104 & 148 \\
\hline
\end{tabular}

Sig: $* * * 0<.01, * * 0<0.05, * p<0.10$

Table 5 A

\section{Environmental Conditions as Predictors of Job Satisfaction}

\begin{tabular}{|c|c|c|c|c|}
\hline \multirow[b]{2}{*}{ PREDICTORS } & \multicolumn{2}{|c|}{ TENURED ONLY } & \multicolumn{2}{|c|}{ NONTENURED ONLY } \\
\hline & $\begin{array}{c}\text { Women } \\
\text { Coef. (Std. Err.) }\end{array}$ & $\begin{array}{c}\text { Men } \\
\text { Coef. (Std. Err.) }\end{array}$ & $\begin{array}{c}\text { Women } \\
\text { Coef. (Std. Err.) }\end{array}$ & $\begin{array}{c}\text { Men } \\
\text { Coef. (Std. Err.) }\end{array}$ \\
\hline (Constant) & $1.359(.329)^{* *}$ & $1.657(.244)^{* * *}$ & $.469(.381)$ & $1.358(.301)^{* * *}$ \\
\hline Climate Collegiality & $.679(.072)^{* * *}$ & $.668(.044)^{* * *}$ & $.637(.098)^{* * *}$ & $.633(.069)^{* * *}$ \\
\hline Tolerance Scale & $-.005(.091)$ & $-.069(.058)$ & $.211(.101)^{* *}$ & $.019(.074)$ \\
\hline Discrimination Experiences & $-.122(.039)^{* * *}$ & $-.073(.033)^{* *}$ & $-.066(.043)$ & $-.125(.053)^{* *}$ \\
\hline Full Professor Dummy & .165 (.111) & $.122(.072)^{*}$ & & \\
\hline R-Squared & .607 & .400 & .469 & .445 \\
\hline No. of Cases & 167 & 484 & 138 & 183 \\
\hline
\end{tabular}

Sig: *** $p<.01,{ }^{* *} p<0.05,{ }^{*} p<0.10$

untenured women. More time spent on mentoring activities is related to lower job satisfaction among tenured women, although more time spent on mentoring activities is related to higher job satisfaction among untenured men. In contrast, a larger number of undergraduate advisees corresponds to lower job satisfaction among the same group (untenured men).

Table ${ }_{4} \mathrm{~B}$ is concerned solely with professional satisfaction. The professional satisfaction scale includes questions about satisfaction with collaborative opportunities, funding for research, and contributions to theory. With the sample split into subgroups, professional recognition is unrelated to professional satisfaction. Teaching release is also unrelated to professional satisfaction. More resources are associated with higher levels of professional satisfaction among tenured men and untenured women. The professional satisfaction of tenured men increases with more award nominations. In general, the more one publishes, the more professionally satisfied one is. This relationship holds among male and female tenured faculty and among nontenured men. More frequent conference attendance is linked to higher levels of professional satisfaction among both male and female tenured faculty and among nontenured men. Teaching more undergraduate courses is linked to depressed professional satisfaction among tenured men. Having to prepare new courses is associated with lower professional satisfaction among tenured women. Informal mentoring affects professional satisfaction among untenured faculty, with more mentoring negatively associated with female satisfaction and positively associated with male satisfaction. Having many undergraduate advisees is associated with lower levels of professional satisfaction among both tenured and untenured men. For untenured women, more committee service is associated with lower levels of professional satisfaction.

We now review the final set of predictors of satisfaction: environmental conditions. According to the results of the model testing as presented in table $5 \mathrm{~A}$, a more positive collegial climate is powerfully associated with greater job satisfaction among all subgroups. Greater tolerance in the workplace is associated with greater job satisfaction among untenured women. Experiences with discrimination negatively affect job satisfaction among male and female tenured faculty and among untenured men. Note that with these controls, job satisfaction is higher among male full professors than among male associate professors.

With regard to professional satisfaction, table ${ }_{5} \mathrm{~B}$ reveals that ratings of one's department as collegial are associated with professional satisfaction among tenured men and women and among untenured men. The tolerance measure is not a significant predictor of professional satisfaction. Experiences with discrimination are negatively related to professional satisfaction among tenured 
Table ${ }_{5 B} B$

Environmental Conditions as Predictors of Professional Satisfaction

\begin{tabular}{|c|c|c|c|c|}
\hline \multirow[b]{2}{*}{ PREDICTORS } & \multicolumn{2}{|c|}{ TENURED ONLY } & \multicolumn{2}{|c|}{ NONTENURED ONLY } \\
\hline & $\begin{array}{c}\text { Women } \\
\text { Coef. (Std. Err.) }\end{array}$ & $\begin{array}{c}\text { Men } \\
\text { Coef. (Std. Err.) }\end{array}$ & $\begin{array}{c}\text { Women } \\
\text { Coef. (Std. Err.) }\end{array}$ & $\begin{array}{c}\text { Men } \\
\text { Coef. (Std. Err.) }\end{array}$ \\
\hline (Constant) & $3.161(.395)^{* * *}$ & $2.661(.258)^{* * *}$ & $2.530(.465)^{* * *}$ & $2.402(.381)^{* * *}$ \\
\hline Climate Collegiality & $.242(.086)^{* * *}$ & $.189(.047)^{* * *}$ & $.183(.120)$ & $.261(.088)^{* * *}$ \\
\hline Tolerance Scale & $-.138(.109)$ & $.021(.061)$ & $.037(.123)$ & $-.008(.094)$ \\
\hline Discrimination Experiences & $-.149(.046)^{* * *}$ & $-.016(.036)$ & $-.010(.052)$ & $-.031(.068)$ \\
\hline Full Professor Dummy & $.368(.133)^{* * *}$ & $.288(.077)^{* * *}$ & & \\
\hline R-Squared & .202 & .079 & .043 & .70 \\
\hline No. of Cases & 164 & 481 & 138 & 183 \\
\hline
\end{tabular}

Sig: ${ }^{*} p<0.05, * 0<0.10$

women. Full professors, whether male or female, are more professionally satisfied than associate professors.

Some of the variables included in our models have a high proportion of missing responses, such as the year of receipt of the $\mathrm{PhD}$ and the number of hours per week spent on mentoring. Thus, the number of cases included in our analysis drops when these variables are included as predictors. For this reason, we also tested the same models using imputed data and holding the number of cases in the analysis constant at 1,063 for the professional satisfaction scale and at 1,069 for the job satisfaction scale. Using imputed estimates of missing responses increases the number of observations considered in the analysis. We use the Amelia II program designed for multiple imputation to impute estimates of the missing responses on each of the independent variables in the analysis (Honaker, King, and Blackwell 2011). ${ }^{9}$ The results using multiple imputation are available from the authors. We note that the analyses using the multiple imputation confirm the results as presented herein and provide additional evidence for the robustness of our findings. The lion's share of the coefficients that are significant in the tables here are also significant in the analyses based on files created by the Amelia program. ${ }^{10}$

\section{Table 6A}

\section{Simplified Summary Model for Job Satisfaction}

\begin{tabular}{lc} 
PREDICTORS & COEFFICIENTS (STANDARD ERRORS) \\
\hline Constant) & $3.464(.080)^{* * *}$ \\
\hline Racial Minority & $-.305(.089)^{* * *}$ \\
\hline Number of Children & $.084(.024)^{* * *}$ \\
\hline Current Department Rank & $.056(.025)^{* *}$ \\
\hline Private Institution & $.286(.064)^{* * *}$ \\
\hline Overall Resource & $.039(.012)^{* * *}$ \\
\hline Award Nominations & $.142(.035)^{* * *}$ \\
\hline Professional Recognition & $-.165(.040)^{* * *}$ \\
\hline R-Squared & .089 \\
\hline No. of Cases & 962 \\
\hline Sig: ${ }^{* * *} p<0.01,{ }^{* *} p<0.05,{ }^{*} p<0.10$ &
\end{tabular}

In table $6 \mathrm{~A}$ we combine men and women, tenured and nontenured, and report a parsimonious model for job satisfaction. We remove from the model factors that had been hypothesized to influence job satisfaction, but for which we could not reject the null hypothesis of no relationship within the full sample. Some of the insignificant variables had several missing responses to the questions that they represent, and, thus, by removing them, we have increased the number of cases on which our results are based. Table 6A represents the result of this exercise when testing the predictive power of the demographic and institutional variables, plus the motivators and hygienes together. In this model, we have not included the scales measuring environmental conditions, as we see these as being conceptually close to our measures of satisfaction and we are faced with an endogeniety issue when the environmental conditions are included in the same model with the other predictors. (Note that in table $5 \mathrm{~A}, 61 \%$ of variance in job satisfaction among tenured women can be explained by reference to the three environmental scales.)

Table 6A reveals that across our full sample of political scientists employed in academia, those who have significantly less job satisfaction compared to their comparative counterparts are members of a minority racial group and those who have served on editorial boards and committees of professional associations (the professional recognition variable). In contrast, job satisfaction improves with children, employment in a more highly ranked department, employment in a private institution, having more resources, and being nominated for teaching, research, or service awards.

With regard to professional satisfaction, from the results reported in table $6 \mathrm{~B}$, we conclude that minorities are less professionally satisfied as are those who teach many undergraduate courses. In addition, those residing in the Northeast, Midwest, or South are less satisfied than those working in the West. Other factors that are significantly associated across the full sample of political science faculty with higher professional satisfaction are employment in a higher ranked department, employment in a private institution, more resources, more award nominations, more publications, and more frequent participation in political science conferences.

To take this analysis further, we use two of the climate variables that are significantly related to satisfaction as dependent variables in OLS regressions to explain why some of our colleagues experience their department environment differently from others. ${ }^{11}$ For this analysis, we report parsimonious models that contain only variables that have significant estimated coefficients in the OLS regressions. We checked multiple variants of these models, and all estimated coefficients remain stable across the models based on the demographic, institutional, and motivator and hygiene variables (i.e., the magnitudes and the significance levels of coefficients do not change depending on which variables 


\section{Table $6 B$}

\section{Simplified Summary Model for Professional Satisfaction}

\begin{tabular}{lc} 
PREDICTORS & COEFFICIENTS (STANDARD ERRORS) \\
\hline Constant) & $3.031(.123)^{* * *}$ \\
\hline Racial Minority & $-.199(.075)^{* * *}$ \\
\hline Current Department Rank & $.110(.023)^{* * *}$ \\
\hline Private Institution & $.186(.056)^{* * *}$ \\
\hline Northeast Regional Dummy & $-.122(.074)$ \\
\hline Midwest Regional Dummy & $-.182(.074)^{* *}$ \\
\hline South Regional Dummy & $-.193(.074)^{* * *}$ \\
\hline Overall Resource & $.032(.011)^{* * *}$ \\
\hline Award Nominations & $.072(.031)^{* *}$ \\
\hline Total Productivity & $.161(.028)^{* * *}$ \\
\hline Frequency of Attending Conferences & $.017(.006)^{* * *}$ \\
\hline Number of Undergraduate Courses & $-.060(.013)^{* * *}$ \\
\hline R-Squared & .236 \\
\hline No. of Cases & 890 \\
\hline Sig.*** $P<0.01 * * 0<0.05 * 0<010$ &
\end{tabular}

\section{Table 7}

\section{Simplified Model for Collegial Climate Scale}

\begin{tabular}{lc} 
PREDICTORS & COEFFICIENTS (STANDARD ERRORS) \\
\hline (Constant) & $3.651(.081)^{* * *}$ \\
\hline Racial Minority & $-.307(.085)^{* * *}$ \\
\hline Married or Partnered & $.271(.078)^{* * *}$ \\
\hline Private Institution & $.194(.061)^{* * *}$ \\
\hline Professional Recognition &. $.152(.036)^{* * *}$ \\
\hline R-Squared & 980 \\
\hline No. of Cases & \\
\hline Sig: ${ }^{* * *} p<0.01,{ }^{* *} p<0.05,{ }^{*} p<0.10$ &
\end{tabular}

are included in the analysis), so we report only significant coefficients in tables 7 and 8.

We present one more hypothesis to guide this component of our research:

H8: Both women and minorities will report less collegiality and more discrimination than their comparative counterparts.

The expectation that we will see differences between men and women and between minorities and nonminorities is based on extensive literature, some of which was mentioned earlier, and also includes the review conducted by Seifert and Umbach (2008, 361-62):

In a study of research university faculty, Bronstein and Farnsworth (1998) found women more often than men reported experiences of
Table 8

\section{Simplified Model for Experiences with Discrimination}

\begin{tabular}{lc} 
PREDICTORS & COEFFICIENTS (STANDARD ERRORS) \\
\hline (Constant) & $-.227(.141)$ \\
\hline Female & $.558(.098)^{* * *}$ \\
\hline Racial Minority & $.844(.131)^{* * *}$ \\
\hline Award Nominations & $.089(.051)^{*}$ \\
\hline Professional Recognition & $.148(.059)^{* *}$ \\
\hline Frequency of Attending Conferences & $.029(.010)^{* * *}$ \\
\hline Number of Undergraduate Courses & $.036(.020)^{*}$ \\
\hline R-Squared & .092 \\
\hline No. of Cases & 910 \\
\hline Sig: $* * * p<0.01,{ }^{* *} p<0.05,{ }^{*} p<0.10$ &
\end{tabular}

gender discrimination characterized by exclusion by colleagues, inappropriate sexual attention, demeaning or intimidating behaviors, and unfair treatment in personnel matters... Women faculty and faculty of color also reported feeling that their colleagues view their research as tangential, self-serving, and that it was not "pure" science (Aguirre, 2000; Bronstein, 1993; California News Reel, 1996; Garza, 1993; Ladson-Billings, 1997).

In addition, in a review provided by Olsen, Maple, and Stage (1995, 270-71):

In their research, Clark and Corcoran [12, p. 25] describe a "Salieri effect," whereby women are assessed by a dominant inner circle of men and fail to "measure up" because of their social status. In the end, the Salieri effect is perhaps more insidious than overt discrimination, because it allows women to enter academe while severely limiting opportunities for advancement. Similarly, investigators describe a kind of "symbolic racism" toward minorities, which denounces overt forms of prejudice while denying access to resources, information, and sources of support (many of which are informal) essential to success [52, see also 18$]$.

Unfortunately our findings corroborate this earlier work. In table 7 , we see that minority faculty members tend to rate their departments as less collegial than nonminority faculty. Faculty who are married or partnered tend to rate their departments as more collegial than faculty who are single. Faculty members who work in private institutions rate their departments as more collegial than those who work in public institutions. The more professional recognition one has received (serving on an editorial board or on a committee in a professional association), the less likely one is to see his or her department as collegial.

In table 8, we see that both minorities and women report significantly more experiences with discrimination than their comparative counterparts. The coefficients associated with being a member of a minority group and with being a woman are both significant when the discrimination experience variable is the dependent variable. Also a larger number of undergraduate courses taught is associated with increasing reports of discrimination. More involvement in the political science profession (more conference attendance and more professional recognition [service 
on editorial boards and professional committees]) is associated with increasing reports of discrimination. More award nominations are associated with greater discrimination experience. ${ }^{12}$

\section{DISCUSSION}

We organize our discussion around the hypotheses presented earlier. Hypothesis 1 is rejected as we do not find systematic differences between men and women in either job or professional satisfaction. We do, however, have striking support for Hypothesis 2: racial minorities do, on average, report less job satisfaction and less professional satisfaction than nonminorities. We note that for job satisfaction, this finding is driven by a relationship that is significant among women. With regard to professional satisfaction, we do not find significant differences between minorities and nonminorities when the sample is split between men and women. ${ }^{13}$

To interpret this information, we start with the correlates of satisfaction that are most proximate to it: the environmental conditions of the job. One environmental factor that is consistently related to job satisfaction is discrimination experience. ${ }^{14}$ Note that discrimination undermines job satisfaction and is more frequently reported by women than men and is also more common among minority faculty than nonminorities.

Our research reveals that, although many refuse to acknowledge and discuss it, discrimination still exists within our profession. Self-reports of actual experiences with discrimination from many respondents cannot and should not be ignored. How can we explain that minorities find their working environment less collegial than nonminorities and that they report more experiences with discrimination than nonminorities? Why do women report more experiences with discrimination than men? One expla- the workplace should be a high priority for both individual faculty members and departmental leadership. This research represents an action call for each of us to improve the collegiality of our work environment. (This is in place of asking the question of what the department leadership should do.) We remind readers that the collegial climate scale represents ratings of the department's degree of respect, friendliness, collegiality, collaboration, and cooperation. Improving these aspects of the work environment is within our control. Each member of every department can be more friendly, respectful, and cooperative with his or her colleagues. A few examples of action that can be initiated by anyone include organizing social events, stopping by each other's offices to say hello, and offering colleagues assistance with their teaching and writing. Our analysis reveals that efforts to improve the collegiality of the department will improve job satisfaction overall.

We turn next to Hypothesis 3. According to this hypothesis, those who work in more highly ranked departments are expected to be more satisfied than those who are employed in less highly ranked departments. Our research reveals strong relationships between institutional variables and satisfaction, thus, providing support of the hypothesis. The finding that those who are working in top ranked departments and/or in private institutions tend to have higher levels of both professional and job satisfaction is rather striking. It also corroborates existing work (Ethington, Smart, and Zeltman 1989; Sabharwal and Corley 2009).

Given the importance of the institutional variables, such as type of institution and ranking of the department, we are reminded of the robust theoretical roots of the idea that "institutions" create in-groups of workers. What can be done? Quite simply, the members of these in-groups need to reach out to nonmembers.

\section{Thus, improving the collegiality for the workplace should be a high priority for both individual faculty members and departmental leadership. This research represents an action call for each of us to improve the collegiality of our work environment.}

nation is the sense of isolation that may come if the faculty member is the only woman or the only minority in the department (Aguirre 2000; Tack and Patitu 1992). Isolation is compounded if other members of the department believe that their female or minority colleague came into the department as a result of an affirmative action hire (Turner and Myers 2000). An underlying belief that the female or the minority colleague did not earn the position, but rather was given the position through an affirmative action program can poison departmental relations. This belief that women or minorities are less qualified must be expunged from the political science profession. It is insidious and cruel. This subtle stereo-typing of one or another of our colleagues as being of lesser quality than another not only undermines the ability of the targeted colleague to enjoy his or her work, it undermines the entire academic endeavor as their work and ideas are shunned as being less legitimate and less worthy. In turn, this undermines academic freedom and intellectual creativity.

For every subgroup of the population tested (men and women, tenured and nontenured), a more collegial working environment is strongly associated with higher levels of both job satisfaction and professional satisfaction. Thus, improving the collegiality of
Those employed in the elite institutions can help faculty members from other colleges and universities become more professionally involved. Networks can be inclusive or exclusive. This is a choice made by network creators and network members. Faculty from private institutions and highly ranked departments should consider purposefully including fellow academics from state institutions or lower ranked departments in their intellectual endeavors and interactions.

In addition, these findings can be considered when one is on the job market. The likelihood of finding happiness with both the department and ones work within the profession is likely to be higher if one seeks and receives employment in a highly rated department and at a private rather than a publicly funded institution. Obviously not everyone can work in a top-ranked department or in a private institution, but these departments are fostering higher levels of satisfaction. Clearly they are doing something right. (Note that these relationships hold even when controlling for the overall level of resources, which also contribute to job and professional satisfaction.) Perhaps highly ranked departments can share their best practices (practices that improve the satisfaction levels of employees) with other colleges and universities. 
Following up on the role of institutional factors in satisfaction, an additional finding is one that does not relate directly to one of the selected hypotheses. This finding is the significance associated with the dummy variables representing in what geographical area in the United States one's institution of employment is located. The findings reveal that women have lower average levels of professional satisfaction in the Northeast and the South, and higher professional satisfaction in the West (the Midwest is not significantly different). When men and women are combined, lower satisfaction is registered in the South and the Midwest (compared with the West), with the Northeast not being significantly different.

With regard to Hypothesis 4, we see that too much undergraduate teaching undermines professional satisfaction, but not job satisfaction (across the full sample). This finding is under- discipline, however, also creates a heightened awareness of what is wrong with the discipline. If one is going to conferences and participating on editorial boards and professional committees, it is harder to ignore the issues that trouble the profession. Note that service on editorial boards and professional association committees (professional recognition) works against job satisfaction and reports of a collegial department, and increases the likelihood of reporting experiences with discrimination. It is possible that the extra work associated with editorial boards and professional committee service could pull faculty members away from regular interaction with departmental colleagues, thus creating a distance associated with collegial interactions. More likely, however, is that professional service leads to greater knowledge of particular inequities that remain characteristic of the political science discipline.

\section{Symbolic rewards are important for job satisfaction. Being nominated for awards is associated with higher levels of satisfaction with one's position and one's colleagues; it is also associated with higher levels of professional satisfaction. Spreading the rewards around might be one way of creating a larger pool of satisfied workers.}

standable given that even if one enjoys teaching, the more time spent in the classroom, the less time is left for collaborating with colleagues in research and making theoretical contributions to the discipline (components of professional satisfaction as measured through our questionnaire). This relationship between a high teaching load and lower levels of professional satisfaction is driven by tenured men-although the relationship is also found (in a weaker form) among nontenured men and women.

Our research also provides confirmation of Hypothesis 5: those in higher academic ranks report higher satisfaction than those in lower ranks. Because both job satisfaction and professional satisfaction tend to be highest among full professors, perhaps these faculty members could take extra responsibility for helping to improve the collegiality of their department for others, which would help improve satisfaction among all ranks.

Symbolic rewards are important for job satisfaction. Being nominated for awards is associated with higher levels of satisfaction with one's position and one's colleagues; it is also associated with higher levels of professional satisfaction. Spreading the rewards around might be one way of creating a larger pool of satisfied workers.

Hypothesis 6 is, in general, confirmed: publishing leads to greater levels of professional satisfaction (or higher professional satisfaction leads to greater productivity in terms of publications). This relationship is robust and holds across the full sample and among all subgroups, except for untenured women. In the Hagedorn (2000) framework, publications represent achievement, which is a motivator that leads to increased satisfaction. If we turn the causal arrow the other way, the finding ties in with the established notion that increased satisfaction improves productivity. Thus, again, we have evidence that improving the work environment is a public good.

How do we explain that attending more conferences is associated with higher levels of professional satisfaction, but also with more reports of discrimination? Clearly professional satisfaction increases with increased participation in the discipline through publications and conference attendance. Increased participation in the

\section{ACKNOWLEDGMENTS}

The survey on which the analyses reported herein are based was funded by the APSA. We are indebted to APSA executive director Michael Brintnall for his support and to Sean Twombly for his assistance. An early version of this article was presented at the Midwest Political Science Annual Meeting in Chicago, April 2012. -

\section{NOTES}

1. Using a series of survey questions about whether students were equally respectful of male and female faculty members, whether the administration treated male and female faculty equally, and whether male faculty members treated women faculty members with respect, the authors created a "chilly climate scale," with high scores indicating consistent reports of inequality in treatment (of female versus male faculty) by students, administration, and other faculty members.

2. The number of external fellowships and grants received would fit perfectly into this category, but it is highly correlated with the total number of publications, so we exclude it from the analysis.

3. Collegial Climate is a five-item scale based on rating the department on friendliness, respect, collegiality, collaboration, and cooperativeness.

4. Tolerance is a five-item scale based on rating the department on racism, sexism, and homophobia.

5. Discrimination Experience is a count of the job-related discrimination experienced by the respondent.

6. The question is similar to the question asked in the NSF-sponsored Survey of Doctorate Recipients of 1997: "How would you rate your overall satisfaction with your principle job during the week of April 15?" The choices are exactly the same as in our survey: Very satisfied, Somewhat satisfied, Neither satisfied nor dissatisfied, Somewhat dissatisfied, and Very dissatisfied.

7. We look only at people who are in a tenure-track position, which represents the lion's share of respondents ( $92 \%)$.

8. We note here that number of children and age are correlated, thus more children may be serving as a proxy for age. We do not include age as control because later age comes into the model through academic rank and because age is correlated with Year of Degree.

9. For multiple imputation work, we used Amelia II version 1.5-2 developed by Honaker, King, and Blackwell (2011). We used the standalone program of AmeliaView in the Windows environment, downloadable from the developers' website at http://gking.harvard.edu/amelia/. We did not impute any missing values in our dependent variables; we only imputed the set of explanatory variables. Our data set contains several ordinal and nominal variables and the Amelia II allows users to classify those variables as having noncontinuous distributions according to their characteristics. In addition, we took a 
(natural) logarithm transformation to any heavily skewed variables or variables with outliers in order to normalize its distribution. Also, if any variable needed to be bounded by realistically possible numbers, we assigned bounds (maximum and minimum values) to those variables using their observed summary statistics. Finally, after AmeliaView produced five multiple imputed data sets in a STATA format (.dta), we used Clarify (Tomz, Wittenberg, and King 2003) for data analysis to combine the results.

10. A couple of additional factors emerge as being significant using the imputed data: among men, being married increases job satisfaction; and a more recen receipt of the doctoral degree is associated with lower professional satisfaction, as is living in the Midwest (compared with other regions). A second set of exceptions occurs when predicting job satisfaction using motivators and hygienes. When using the imputed data to predict job satisfaction, we find that among tenured women award nominations is not significant; among tenured men, professional recognition and total productivity are significant; and among nontenured men, mentoring activities are not significant, although released from teaching is significant. When we use the imputed data to predict professional satisfaction from motivators and hygienes, the results differ from those reported here in the following ways: among tenured women, conference attendance and new course preparation are not significant while mentoring activities are; among tenured men, neither conference attendance nor number of undergraduate advisees is significant; among nontenured women, the number of undergraduate courses taught is significant; and among nontenured men, both professional recognition and the number of undergraduate courses is significant using the imputed data. With regard to predicting satisfaction using environmental conditions, the only finding that differs from the results reported in tables ${ }_{5} \mathrm{~A}$ and ${ }_{5} \mathrm{~B}$ is that when predicting professional satisfaction among nontenured women, the collegial climate scale is significant when using the imputed data.

11. We do not do additional analysis on the tolerance variable, as it is the environmental condition least associated with satisfaction. Given that collegial climate and discrimination are more important for understanding satisfaction, we follow up on these and not tolerance.

12. Our results using imputed values for responses missing on predictor variables confirm the relationships documented in tables 7 and 8 . One additional variable emerges as a significant predictor of perceptions of a collegial climate: award nominations. An additional finding from the analysis of discrimination experience as the dependent variable using the imputed data is that a more recent receipt of the doctoral degree (year of degree) is associated with more frequent reports of discrimination experience. Also discrimination is more frequently reported by those working in the northeast region of the country.

13. Contrary to the literature, we also note that certain demographic and job characteristics are generally not related to variation in satisfaction: these include whether one is married or partnered, and whether one has a joint appointment.

14. The exception is that we do not see this relationship between discrimination experience and job satisfaction among nontenured women.

\section{REFERENCES}

Aguirre, A. 2000. "Women and Minority Faculty in the Academic Workplace: Recruitment, Retention and Academic Culture." ASHE-ERIC Higher Education Report 27 (6). Washington. DC: American Association for Higher Education.

Aisenberg, N., and M. Harrington. 1988. Women of Academe: Outsiders in the Sacred Grove. Amherst: University of Massachusetts Press.

Antonio, A. L., C. M. Cress, and A. W. Astin. 1997. "Faculty Diversity: Faculty of Color Still Low in Numbers and Ranking: But Latino/as Report High Job Satisfaction." The Hispanic Outlook in Higher Education 7 (26): 14.

August, L., and J. Waltman. 2004. "Culture, Climate, and Contribution: Career Satisfaction among Female Faculty." Research in Higher Education 45: 177-92.

Austin, H., and D. Davis. 1985. "Research Productivity across the Life and Career Cycles: Facilitators and Barriers for Women." In Scholarly Writing and Publishing: Issues, Problems and Solutions, ed. M. F. Fox, 147-16o. Boulder, CO: Westview Press.

Bender, K. A., and John S. Heywood. 2009. "Educational Mismatch among Ph.D.s: Determinants and Consequences." In Science and Engineering Careers in the United States: An Analysis of Markets and Employment, eds. R. B. Freeman and D. L. Goroff. Chicago: The University of Chicago Press.

Bender, Keith A., and John S. Heywood. 2006. "Job Satisfaction of the Highly Educated." Scottish Journal of Political Economy 53 (2): 253-79.

Bilimoria, D., S. R. Perry, X. Liang, E. P. Stoller, P. Higgins, and C. Taylor. 2006. "How Do Female and Male Faculty Members Construct Job Satisfaction? The Roles of Perceived Institutional Leadership and Mentoring and Their Mediating Processes." Journal of Technology Transfer 31: 355.

Blackburn, R. T., and J. H. Lawrence. 1995. Faculty at Work: Motivation, Expectation, Satisfaction. Baltimore: Johns Hopkins University Press.

Bronstein, P. 1993. "Challenges, Rewards, and Costs for Feminist and Ethnic Minority Scholars." New Directions for Teaching and Learning 53: 61-70.

Bronstein, P., and L. Farnsworth. 1998. "Gender Differences in Faculty Experiences of Interpersonal Climate and Processes for Advancement." Research in Higher Education 39 (5): 557-85.
Bryson, R., J. B. Bryson, and M. F. Johnson. 1978. "Family Size, Satisfaction, and Productivity in Dual-Career Couples." Psychology of Women Quarterly 3 (1): 67-77.

California News Reel (Producer). 1996. Shattering the Silences: Minorities Break into the Ivory Tower [Motion picture]. United States.

Callister, R. R. 2006. "The Impact of Gender and Department Climate on Job Satisfaction and Intentions to Quit for Faculty in Science and Engineering Fields." Journal of Technology Transfer 31: 367-375.

Carnevale, D. G., and J. M. Rios. 1995. "How Employees Assess the Quality of Physical Work Settings." Public Productivity and Management Review 18: 221-31.

Carr, P. L., and A. S. Ash. 1998. "Relation of Family Responsibilities and Gender to the Productivity and Career Satisfaction of Medical Faculty." Annals of Internal Medicine 129: $53^{2-38}$.

Cetin, M. O. 2006. "The Relationship between Job Satisfaction, Occupational and Organizational Commitment of Academics." Journal of American Academy of Business, Cambridge 8 (1): 78-88.

Ethington, C. A., J. C. Smart, and M. L. Zeltman. 1989. "Institutional and Departmental Satisfaction of Women Faculty." Research in Higher Education 30: 261-71.

Garza, H. 1993. "Second-Class Academics: Chicano/Latino Faculty in U.S. Universities." New Directions for Teaching and Learning 53: 33-41.

Gruneberg, M. M. 1979. Understanding Job Satisfaction. London: The Macmillan Press Ltd.

Hagedorn, L. S. 1996. "Wage Equity and Female Faculty Job Satisfaction: The Role of Wage Differentials in a Job." Research in Higher Education 37 (5): 569-98.

Hagedorn, L. S. 200o. "Conceptualizing Faculty Job Satisfaction: Components, Theories, and Outcomes." New Directions for Institutional Research 105: 5-20.

Herzberg, F., B. Mausner, and B. Snyderman. 1959. The Motivation to Work (2nd rev. ed.). New York: Wiley.

Hesli, Vicki, and Barbara Burrell. 1995. "Faculty Rank among Political Scientists and Reports on the Academic Environment: The Differential Impact of Gender on Observed Patterns." PS: Political Science and Politics 28 (2): 101-11.

Hesli, Vicki, Jacqueline DeLaat, Jeremy Youde, Jeanette Mendez, and Sang-shin Lee. 2006. "Success in Graduate School and After: Survey Results from the Midwest Region." PS: Political Science and Politics 39 (2): 317-25.

Hesli, Vicki, Evelyn C. Fink, and Diane Duffy. 2003. "The Role of Faculty in Creating a Positive Graduate Student Experience: Survey Results from the Midwest Region, Part II." PS: Political Science and Politics 36 (4): 801-04.

Hesli, Vicki, Jae Mook Lee, and Sara Mitchell. 2012. "Predicting Rank Attainment in Political Science: What Else Besides Publications Affects Promotion?" PS: Political Science \& Politics 45 (3): 475-92.

Holder, J. C., and A. Vaux. 1998. "African American Professionals: Coping with Occupational Stress in Predominantly White Work Environments." Journal of Vocational Behavior 53 (3): 315-33.

Honaker, J., Gary King, and M. Blackwell. 2011. Amelia II: A Program for Missing Data. http://r.iq.harvard.edu/docs/amelia/amelia.pdf. Accessed on July 18, 2011

Hult, C., R. R. Callister, and K. Sullivan. 2005. "Is There a Global Warming toward Women in Academia?" Liberal Education 91: 50-57.

Johnsrud, L. K., and C. D. Des Jarlais. 1994. "Barriers to the Retention and Tenure of Women and Minorities: The Case of a University's Faculty." Review of Higher Education 17: 335-53.

Kalleberg, A. 1977. "Work Values and Job Rewards: A Theory of Job Satisfaction." American Sociological Review 42 (1): 124-43.

Ladson-Billings, G. 1997. "For Colored Girls Who Have Considered Suicide When the Academy's Not Enough: Reflections of an African American Woman Scholar." In Learning from Our lives: Women, Research, and Autobiography in Education, eds. A. Neumann and P. Peterson. New York: Teachers College Press.

Lahey, K. E., and J. L. Vihtelic. 20oo. "Finance Faculty Demographics, Career History, Diversity, and Job Satisfaction." Financial Practice and Education 10 (1): $111-22$.

Leung, T., O. Siu, and P. E. Spector. 200o. "Faculty Stressors, Job Satisfaction, and Psychological Distress among University Teachers in Hong Kong: The Role of Locus of Control." International Journal of Stress Management 7: 121-38.

Liu, M. C. 2001. "The Adaptation and Experience of Foreign-Born Faculty Members in the United States." PhD Thesis, Claremont Graduate University.

Niemann, Y. F., and J. F. Dovidio. 1998. "Relationship of Solo Status, Academic Rank, and Perceived Distinctiveness to Job Satisfaction of Racial/Ethnic Minorities." Journal of Applied Psychology 83 (1): 55-71.

Okpara, J. O., M. Squillace, and E. A. Erondu. 2005. "Gender Differences and Job Satisfaction: A Study of University Teachers in the United States." Women in Management Review 20 (3-4): 177-90.

Olsen, D., S. A. Maple, and F. K. Stage. 1995. "Women and Minority Faculty Job Satisfaction: Professional Role Interests, Professional Satisfactions, and Institutional Fit." The Journal of Higher Education 66 (3): 267-93.

Oshagbemi, T. 1997. "Job Satisfaction Profiles of University Teachers." Journal of Managerial Psychology 12 (1): 27-39. 
Peterson, N. B., R. H. Friedman, A. S. Ash, S. Franco, and P. L. Carr. 2004. "Faculty Self-Reported Experience with Racial and Ethnic Discrimination in Academic Medicine." Journal of General Internal Medicine 19 (3): 259-65.

Ponjuan, L. 2005. "Understanding the Work Lives of Faculty of Color: Job Satisfaction, Perception of Climate, and Intention to Leave." Dissertation Abstracts International 66(o8-A), UMI No. AAT3186734.

Rosser, V. J. 2004. "Faculty Members' Intentions to Leave: A National Study on Their Worklife and Satisfaction." Research in Higher Education 45 (3): 223-34.

Rosser, V. J. 2005. "Measuring the Change in Faculty Perceptions over Time: An Examination of Their Worklife and Satisfaction." Research in Higher Education 46 (1): 81-107.

Sabharwal, M., and E. A. Corley. 2009. "Faculty Job Satisfaction across Gender and Discipline." The Social Science Journal 46: 539-56.

Schmidt, B. M., and M. M. Chingos. 2007. "Ranking Doctoral Programs by Placement: A New Method," PS: Political Science and Politics 40 (3): 523-29.

Seifert, T., and P. Umbach. 2008. "The Effects of Faculty Demographic Characteristics and Disciplinary Context on Dimensions of Job Satisfaction." Research in Higher Education 49: 357-81.

Settles, I. H., L. M. Cortina, J. Malley, and A. J. Stewart. 2006. “The Climate for Women in Academic Science: The Good, the Bad, and the Changeable." Psychology of Women Quarterly 30: 47-58.

Smart, J. 1990. "A Causal Model of Faculty Turnover Intentions." Research in Higher Education 31 (5): 405-24.
Sorcinelli, M. D., and A. E. Austin, eds. 1992. "Developing New and Junior Faculty," New Directions for Teaching and Learning, No. 50. San Francisco: Jossey-Bass.

Sousa-Poza, A., and A. A. Sousa-Poza. 200o. "Taking Another Look at the Gender/ Job-Satisfaction Paradox.” Kyklos 53: 135-52.

Tack, M. W., and C. L. Patitu. 1992. Faculty Job Satisfaction: Women and Minorities in Peril. ASHE-ERIC Higher Education Report no. 4. Washington, DC: Association for the Study of Higher Education.

Tomz, Michael, Jason Wittenberg, and Gary King. 2003. "CLARIFY: Software for Interpreting and Presenting Statistical Results." Journal of Statistical Software 8 (1).

Turner, C. S. V., and S. Myers. 200o. Faculty of Color in Academe: Bittersweet Success. Needham Heights, MA: Allyn \& Bacon.

US Department of Education (a). Institute of Education Sciences, National Center for Education Statistics, "Table 266: Full-time and part-time faculty and instructional staff in degree-granting institutions, by race/ethnicity, sex, and program area: Fall 1998 and fall 2003 " at http://nces.ed.gov/programs/digest/ d10/tables/dt10_266.asp?referrer=list.

US Department of Education (b). National Center for Education Statistics, 2004 National Study of Postsecondary Faculty (NSOPF:04).

Ward, M. E., and P. J. Sloane. 20oo. "Non-Pecuniary Advantages versus Pecuniary Disadvantages: Job Satisfaction among Male and Female Academics in Scottish Universities." Scottish Journal of Political Economy 47 (3): 273-303.

\section{APPENDIX A: Survey Methodology}

\section{QUESTIONNAIRE DESIGN}

In 2005, the APSA Committee on the Status of Women in the Profession (CSWP) proposed to the president of APSA that the association conduct research associated with the recommendations that emerged from the March 2004 Workshop on Women's Advancement in Political Science organized by Michael Brintnall and Linda Lopez (American Political Science Association), Susan Clarke (University of Colorado, Boulder), and Leonie Huddy (Stony Brook University). After the research proposal was approved, the CSWP used questionnaires that had been used in research published by Hesli and Burrell (1995), Hesli, Fink, and Duffy (2003) and Hesli, DeLaat, Youde, Mendez, and Lee (2006) to develop a new survey instrument. Additional questions were added from questionnaires developed by the National Research Council and the University of Michigan's fall 2001 Survey of Academic Climate and Activities, which was created for an NSF ADVANCE project. The following reports were also used to help generate questions.

Blau, F. 2002. Report of the Committee on the Status of Women in the Economics Profession. American Economic Review 92: 516-20.

Commission on Professionals in Science and Technology (CPST). 2000. Professional Women \& Minorities: A Total Human Resource Data Compendium, 13th edition. Washington, DC: CPST.

Creamer, Elizabeth. 1998. Assessing Faculty Publication Productivity: Issues of Equity. ASHE-ERIC Higher Education Report 26 (2).

Washington, DC: The George Washington University.

Fox, Mary Frank. 1995. “Women and Scientific Careers." In S. Jasanoff, J. Markle, J. Petersen, and T. Pinch, eds., Handbook of Science and Technology Studies (pp. 205-223). Newbury Park, CA: Sage.

Fox, Mary Frank. 1998. "Women in Science and Engineering: Theory, Practice, and Policy in Programs." Signs: Journal of Women in Culture and Society 24 (Autumn): 201-23.

Sarkee, Meredith Reid and Nancy E. McGlen. 1992. Confronting Barriers: The Status of Women in Political Science, Journal of Women, Politics \& Policy 12 (4) 43-86.

A draft of the questionnaire was circulated to the members of the APSA status committees. The questionnaire was revised and expanded to address the concerns of the members of the status committees. The instrument was pilot tested by distributing it to all political science faculty members at one research university and at one private four-year college. The feedback from the pilot test was used to make further revisions in the questionnaire.

\section{SAMPLE SELECTION}

We used as our target population the names contained within the APSA "faculty" file. We used this file of 11,559 names to create a sample population file of 5,179 names. The original "faculty" file was stratified by department size. To ensure the adequate representation of faculty members from medium and small size schools we over-sampled from these. Names were selected randomly from the "faculty" file for the "sample" file.

\section{SURVEY PROCEDURE}

Using e-mail addresses, all persons in the sample file were sent a letter of invitation to participate in the study from the executive director and the president of the APSA. Incorrect e-mail addresses (addresses that bounced back) were replaced with random selections from the "faculty" file. These persons were also mailed an invitation letter. The cleaned "survey" file was sent to the Survey Research Center (SRC) at the Pennsylvania State University. 


\section{APPENDIX A: (Continued)}

Individuals in the sample were sent an e-mail from SRC inviting them to participate in the survey. This invitation included a link to the webbased survey containing a unique identifier for each potential participant. Only one completed survey was allowed for each identifier.

The initial invitation was e-mailed to respondents on August 27, 2009. Follow-up reminders were sent to nonresponders on September 10 , 2009 , September 24, 2009, October 8, 2009, and October 29, 2009. From among the 5,179 original addresses, 1,399 completed the survey (252 invalid addresses, 105 refusals, and 3,423 nonrespondents).

Among the total set of respondents, $68 \%$ are men and $32 \%$ are women. According to APSA data, the percent of women in the population from which we drew the sample (all political science faculty members in the United States) was 28\% (in 2009). Table A1 shows the percent of survey respondents at each rank alongside of the percent of faculty members in each rank throughout the United States according to APSA data for 2009. With regard to respondents' gender, among assistant professors, $45 \%$ were women; among associates, $28 \%$ were women and among full professors, $24 \%$ were women. The corresponding numbers for the population as a whole are in the table A1.

Table A1

Survey Respondents and the Population

\begin{tabular}{l|cc|cc} 
& \multicolumn{2}{|c|}{ PERCENT OF TOTAL } & \multicolumn{2}{c}{ PERCENT WITHIN RANK WHO ARE FEMALE } \\
\cline { 2 - 5 } RANK & $\begin{array}{c}\text { Survey Respondents } \\
\text { (tenure track only) }\end{array}$ & $\begin{array}{c}\text { The Population } \\
\text { (2009 APSA data) }\end{array}$ & $\begin{array}{c}\text { Survey Respondents } \\
\text { (tenure track only) }\end{array}$ & $\begin{array}{c}\text { The Population } \\
\text { (2009 APSA data) }\end{array}$ \\
\hline Assistant & 28 & 28 & 45 & 39 \\
\hline Associate & 26 & 26 & 28 & 30 \\
\hline Full & 37 & 35 & 24 & 19 \\
\hline
\end{tabular}

\section{APPENDIX B: Variables Included}

Dependent Variables:

Using seven questions relevant to the career satisfaction of respondents, we conducted factor analysis, and two separate dimensions emerged. Given these results, we named those two scales Job Satisfaction and Professional Satisfaction respectively.

Job Satisfaction: The first scale was constructed using a mean of the following three questions (Cronbach's Alpha $=0.793$ );

How satisfied are you with your current position?

a. Very satisfied

b. Somewhat satisfied

c. Neither satisfied nor dissatisfied

d. Somewhat dissatisfied

e. Very dissatisfied

How are you satisfied with the following dimensions of your professional development?

\begin{tabular}{ccccc} 
VERY & SOMEWHAT & & SOMEWHAT & VERY \\
SATISFIED & SATISFIED & NEUTRAL & DISSATISFIED & DISSATISFIED \\
\hline
\end{tabular}

Sense of being valued as a teacher by members of my unit/department

Level of intellectual stimulation in my day to day contacts with faculty colleague

Professional Satisfaction: Given the results of the factor analysis above, the second career satisfaction scale was constructed using a mean of the following three questions (Cronbach's Alpha = 0.677);

\begin{tabular}{ccccc} 
& VERY & SOMEWHAT & SOMEWHAT & VERY \\
DISSATISFIED & DISSATISFIED \\
\hline
\end{tabular}

Opportunity to collaborate with other colleagues in academia

Level of funding for my research

Sense of contributing to theoretical developments in my discipline

For above two satisfaction scales, we kept the scale if two or more of the three items are available using "MEAN.2" function in SPSS to minimize the number of missing values. 


\section{APPENDIX B: (Continued)}

Independent Variables:

Female: "What is your gender? a. Male, b. Female, c. Transgender" The dummy variable equals 1 if the response is b.

Married: "What is your personal status? a. Never married, b. Married (first time), c. Married (second or third time), d. Member of an unmarried opposite or same-sex partnership, e. Separated/divorced, f. Widowed" The dummy variable equals 1 if the response is b, c, or $d$.

Number of Children: "Do you or a spouse/partner of yours have any children? a. Yes (If yes, how many?), b. No" An interaction variable between a dummy for having children (response a.) and the number of children specified.

Minority: "Do you identify yourself as a member of an ethnic and racial minority group? a. Yes, b. no, c. Don't know" The dummy variable equals 1 if the response is a.

Year of Degree: "In what year did you obtain your degree?"

Current Program Ranking: A ranking of the department where the respondent is currently working. The program is ranked based on Schmidt and Chingos (2007); Top 25 (1), Top 26-50 (2), Top 51-75 (3), Top 76-86 (4), and Unranked (5). Then the score is reversed so that higher numbers represent higher ranked department.

Joint Appointment: "Do you hold a joint appointment? a. Yes, b. No" The dummy variable equals 1 if the response is a.

Private institution: "Is this a public or a private institution? a. Public, b. Private" The dummy variable equals to 1 if the response is b.

PhD. Program: “Type of department where you are employed: a. PhD granting program, b. MA granting program, c. Department within a 4-year college, d. Department within a 2-year college, e. Other academic unit (specify)" The dummy variable equals 1 if the response is a.

MA Program: Same question as above, with the dummy variable equals to 1 if the response is $b$.

Number of undergraduate courses: "During the past five years, what is your typical teaching load each year? (If in your current position for less than five years, base this on the period since your appointment.)

Number of undergraduate courses"

New Course Preparation: For this variable, we used the answer to the following question, "In the past 5 years, how many new courses (courses that you have not taught previously-do not include even major revisions of courses you have taught before) have you prepared for your department or college (if you have a joint appointment, refer to your primary unit)?

Informal Mentoring: we used the answer to the following question, "On average, how many hours per week do you spend on informal mentoring activities (e.g. advising, counseling, advocating for graduate or undergraduate students or junior faculty who are not your advisees)?

Number of Undergraduate Advisees: We used the answer to the following question, "For how many of each of the following types of individuals do you currently serve as official advisor? undergraduates"

Release From Teaching: We summed up the answers to each item of the following question, "In the past 5 years, how many courses have you been released from teaching for the following reasons:"

(Indicate how many next to each category.)

with your own grant or fellowship funds

by your department

administrative work

modified duties

routine leave (e.g., development leave/sabbatical)

maternity and/or parental leave

Northeast: Regional dummy for location of the respondent's institution (same for Midwest and South). West is the excluded category.

Tenured: If a respondent answered that his or her position is tenure-track, he or she is provided an additional question asking "If yes (tenuretrack position), where is you in the tenure process? a. tenured, b. working on tenure, c. denied tenure, in the process of moving." The dummy variable equals 1 if the response is a. 


\section{APPENDIX B: (Continued)}

Resources Available: We counted the number of yes responses to the following question: "Have you received any of the following resources as a result of your own negotiations, the terms of an award, or as part of an offer by the university, since your initial contract at your current position? If so, please check all that apply."

\section{ASKED/BARGAINED FOR BY ME PART OF AN EXTERNAL AWARD OFFERED BY UNIVERSITY}

\begin{tabular}{l}
\hline Course release time \\
\hline Research assistant \\
\hline Discretionary funds \\
\hline Travel funds \\
\hline Summer salary \\
\hline Special timing of tenure track \\
\hline Moving expenses \\
\hline Housing subsidy \\
\hline Child care \\
\hline Partner/spouse position \\
\hline Other ( please specify)
\end{tabular}

Award Nominations: We counted the number of yes responses to the following question: "Do you know whether your department or institution has ever nominated you for an award in the following areas? (Please check appropriate box.)"

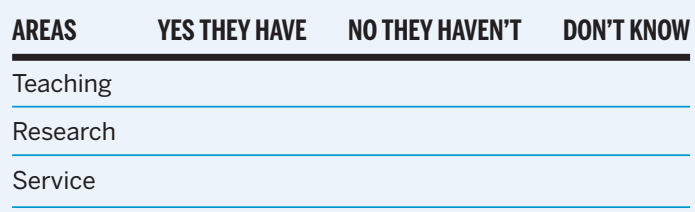

Professional Recognition: We counted the number of one or more to the following question: "In terms of service for your profession, please indicate the number of times (in the past five years) you have done any of the following: (Indicate how many next to each category)" served on an editorial board (number of different boards) served as an external reviewer for another institution (such as for tenure and promotion, etc.)

Frequency of Attending Political Science Conferences: we used the answer to the following question: "How often have you attended political science conferences in the past 3 years? \# of times

Number of Committees: "In a typical year during the past five years, on how many committees do you serve?"

Faculty Rank: “Title of your primary current appointment”

We created an ordinal variable using the following coding: 1 (instructors, lecturers, postdocs and fellows), 2 (assistant professors), 3 (associate professors) and 4 (full professors, emeritus, and administrative positions).

Total Productivity: Question: "For your entire career, please give your best estimate of the number you have produced or have been awarded for each of the following.

number of articles published in referred academic or professional journals

number of monographs (books) published

number of books edited

number of book chapters published"

All missing values of articles, monographs, edited books and book chapters are set to zero, then we took a logarithmic transformation of the sum of these items plus one.

Climate Collegial Scale: Using the total nine survey items relevant to departmental and institutional climate, we ran factor analysis, and the two separate dimensions loaded. Given these results, we named those two scales "Collegial Climate" and "Tolerance Scale" respectively. The first scale (Collegial Climate) was constructed using a mean of the following five items (Cronbach's Alpha = 0.895);

(continued) 


\section{APPENDIX B: (Continued)}

Please rate the climate of your unit(s)/department(s) on the following continuum by selecting the appropriate number (Check the appropriate box.). For example, in the first row, the value 1 indicates hostile while the value 5 indicates friendly, and the numbers in between represent relative combinations of each.

\begin{tabular}{lllllll} 
RATING SCALE & $\mathbf{1}$ & $\mathbf{2}$ & $\mathbf{3}$ & $\mathbf{4}$ & $\mathbf{5}$ & RATING SCALE \\
\hline Hostile & & & & & Friendly \\
\hline Disrespectful & & & & Respectful \\
\hline Contentious & & & & Collegial \\
\hline Individualistic & & & Collaborative \\
\hline Competitive & & & & Cooperative \\
\hline
\end{tabular}

For this scale, we kept the scale if more than three of all five items are available using "MEAN.3" function in SPSS to minimize the number of missing values.

Tolerance Scale: Given the results of the factor analysis above, the Tolerance Scale was constructed using a mean of the following three items (Cronbach's Alpha= 0.835);

Please rate the climate of your unit(s)/department(s) on the following continuum by selecting the appropriate number (Check the appropriate box.). For example, in the first row, the value 1 indicates hostile while the value 5 indicates friendly, and the numbers in between represent relative combinations of each.

\begin{tabular}{lllllll} 
RATING SCALE & $\mathbf{1}$ & $\mathbf{2}$ & $\mathbf{3}$ & $\mathbf{4}$ & $\mathbf{5}$ & RATING SCALE \\
\hline Racist & & & & Non-racist \\
\hline Sexist & & & & Non-sexist \\
\hline Homophobic & & & & Non-Homophobic \\
\hline
\end{tabular}

For this scale, we kept the scale if more than two of all three items are available using "MEAN.2" function in SPSS to minimize the number of missing values.

Discrimination Experience: We counted the number of positive answers (items checked) in the following survey items relevant to any discriminating experiences felt by respondents;

Please indicate in the chart below any job-related discrimination you personally have experienced at your institution within the last five years, noting the basis for the discrimination (race/ethnicity, gender, sexual orientation, etc.). Please check all that apply.

SEXUAL
ORIENTATION

POLITICAL VIEW

RELIGIOUS

PHYSICAL

\section{RACE/ETHNICITY GENDER ORIENTATION POLITICALVIEW AFFILIATION DISABILITY}

\begin{tabular}{l}
\hline Hiring \\
\hline Promotion \\
\hline Salary \\
\hline Space/Equipment, other resources \\
\hline Access to administrative staff \\
\hline Graduate student or resident/fellow \\
assignments \\
\hline Other (please specify):
\end{tabular}

